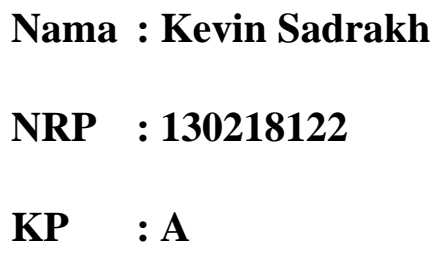

\title{
Government Efforts to Increase MSME Sales in Indonesia
}

When the Covid-19 pandemic in Indonesia, Indonesia's economy experienced a very drastic decline, especially when the government issued regulations on Large-Scale Social Restrictions (Indonesian: Pembatasan Sosial Berskala Besar/PSBB). The existence of PSBB policy makes many trade sectors unable to run their businesses because of limitations in conducting business activities. Many Indonesian people, especially those with upper middle incomes, prefer to use their money to save rather than be used to buy necessities and wants. This is because people do not know when the Covid-19 pandemic will end soon, so the money owned by the upper middle social class is stored in investments. Due to savings from the community, the business sector that impacts food and beverage, construction, manufacturing, trade, transportation, tourism, and others. Based on the results of a survey conducted by the Central Bureau of Statistics in Indonesia (Indonesian: Badan Statistik Indonesia/BPS) shows that the decrease in purchasing power of the community caused a decrease in revenue to MSMEs by $84.7 \%$.

MSMEs contribute to provide $61.1 \%$ of Indonesia's Gross Domestic Product (GDP) so that when there is a decrease in revenue in MSMEs, it also has an impact on indonesia's GDP decrease. Based on Law No. 20 of 2008 concerning Micro, Small and Medium Enterprises (MSMEs), small traders are classified as a group of micro businesses with assets of no more than Rp 50 million and a maximum turnover of $\mathrm{Rp} 300$ million per year. The government is making efforts to restore the economy and reduce the rate of Covid-19 growth in Indonesia. The government provided Rp 203.9 trillion in aid for social protection during the Covid-19 pandemic in 2020. The government is also preparing a strategy to save micro, small, and medium enterprises (MSMEs) by providing social assistance, tax incentives, relaxation, and credit restructuring, to expand financing. Many efforts to develop and empower MSMEs have been carried out by the Central Government, Provinces, Districts, and Cities, including stateowned enterprises and regional-owned enterprises. The government has prepared a budget of Rp 28 trillion to help business capital to 12 million small and ultra micro entrepreneurs by 
2020. The purpose of government assistance is to increase people's purchasing power, reduce poverty and unemployment.

Then, efforts to improve MSMEs in Indonesia by cooperating with several related parties such as macro entrepreneurs, small, medium, and related parties. It is expected that this cooperation will provide good results so that there is a symbiosis of mutualism so that it can cover various losses due to the Covid-19 pandemic. MSME businesses should not drop each other's businesses. It takes support with fellow owners and the government. Profitable relationships must continue to be developed, for example with fellow MSMEs, cooperatives, private companies, state-owned enterprises or regional-owned enterprises, and large businesses.

Nowadays, many Indonesians are beginning to understand technology and use the internet in carrying out their activities such as making purchases, payments, transportation, and others. Butaccording to the Ministry of Cooperatives and MSMEs, the number of MSMEs utilizing digital technology is only 8 million or about $13 \%$ of the total MSMEs. The low number of MSMEs using digital technology is caused by technological mastery constraints and unequal knowledge of online payment technology. The government has been engaged in educating MSME owners to start using the internet in running their businesses in order to compete globally and nationally. Efforts are made by providing knowledge about online sales, supply chain systems are changed in the form of online trading, production, promotion, marketing, and payment using the internet. Many believe that MSME recovery programs are able to overcome poverty and unemployment and encourage economic growth, both local and national. The local government that has many MSMEs seeks to provide assistance, credit, mentoring, online training, online bazaars, and stimulus funds to help manage halal certificates and permits for umkm home industry products in an effort to encourage MSMEs to survive the Covid-19 pandemic.

With the rapid development of technology, the price of mobile phones is now cheaper and affordable so that all circles can buy and use. In addition, credit packages and internet packages are getting cheaper and easier to get helping MSMEs in making sales online. MSMEs can also make sales with e-commerce platforms, such as Bukalapak, Tokopedia, Shopee, Gojek, Grab, Lazada. Various strategies have been carried out by the government to help MSMEs to be managed properly, efficiently, and effectively starting from as a means of sales channels, payments are getting easier with the help of online banks. Currently, the 
developmentof MSMEs cannot be separated from theuse of information technology, considering digitalization is the key for businesses to be able to survive and develop in the midst of the Covid-19 pandemic.

MSME businesses in Indonesia such as culinary, fashion, automotive, tour and travel, creative products, beauty, health, and others. One of the MSMEs in Indonesia is The Kilisuci which sells a variety of fashion products ranging from wedding clothes, suits, shirts, tops. Msmes was founded by Inin Shilviana Nurul. The Kilisuci opened its first business in 2010 in Yogyakarta. The manufacture of fashion products takes the theme of local wisdom with the main materials namely prodo and surjan (two types of traditional fabrics in Java). Until now, MSMEs are still running despite a huge decrease in profit. Because of the Covid-19 pandemic, MSMEs suffered many losses due to the absence of income but operational costs still had to be met. Inin Shilviana, who is the founder of The Kilisuci hopes that the Covid-19 pandemic can end soon and his business can return to normal. To maintain its business, Inin Shilviana started selling fashion products through e-commerce such as Tokopedia, Shopee, and Bukalapak. Inin said when started selling online, revenue began to increase. As well as with the government's help by holding exhibitions MSMEs give a positive impact.

\section{References:}

Tayibnapis, A. Z., Wuryaningsih, L. E., dan Gora, R. (2021). Medium, Small and Medium Enterprises and Digital Platforms. South Asian Journal of Social Studies and Economics. DOI: $10.9734 /$ SAJSSE/2021/v10i230258 